\title{
The Role of Financial Technology in The Creative Industries in Indonesia
}

\author{
Nono Heryana ${ }^{1}$ \\ Program Studi Sistem Informasi \\ Fakultas Ilmu Komputer \\ Universitas Singaperbangsa Karawang \\ Email: nono@unsika.ac.id
}

\author{
Rini Mayasari ${ }^{2}$ \\ Program Studi Sistem Informasi \\ Fakultas Ilmu Komputer \\ Universitas Singaperbangsa Karawang \\ Email: rini.mayasari@staff.unsika.ac.id
}

\author{
Rudi Aprianto ${ }^{3}$ \\ Program Studi Sistem Informasi \\ STMIK Pringsewu \\ Email: rudiaprianto@gmail.com
}

\begin{abstract}
In the modern era, the use of technology is growing rapidly to obtain information and various other electronic services, many people who already use technology, especially the internet to facilitate their work. Seeing the rapid development of the internet has given rise to various innovations, especially financial technology to meet the various needs of the community including access to financial services and transaction processing. Fintech (Financial Technology) is an innovation in the financial sector that refers to modern technology used to transact, check deposit rates, transfer funds, and perform various other financial services. The creative industries are an industry that utilizes the creativity and skills of individuals use as goods of value. The purpose of this study is to determine the role of financial technology and its constraints in the creative industry in Indonesia. The existence of innovation and creativity that arises in the community, making the creative industry is an essential role in the development of a regional economy. The research method used in writing this article is descriptive qualitative. Thus, qualitative research only describes responses to situations or events so that it does not explain causality or do hypothesis testing.
\end{abstract}

Keywords-Financial Technology, Creative Industry, Internet, Indonesia

Abstrak-Di era modern, penggunaan teknologi berkembang pesat untuk memperoleh informasi dan berbagai layanan elektronik lainnya, banyak orang yang sudah menggunakan teknologi, terutama internet untuk memudahkan pekerjaan mereka. Melihat pesatnya perkembangan internet telah memunculkan berbagai inovasi, terutama teknologi keuangan untuk memenuhi berbagai kebutuhan masyarakat termasuk akses ke layanan keuangan dan pemrosesan transaksi. Fintech (Teknologi Finansial) adalah inovasi di sektor keuangan yang mengacu pada teknologi modern yang digunakan untuk bertransaksi, memeriksa suku bunga simpanan, mentransfer dana, dan melakukan berbagai layanan keuangan lainnya. Industri kreatif adalah industri yang memanfaatkan kreativitas dan keterampilan yang digunakan individu sebagai barang yang bernilai. Tujuan dari penelitian ini adalah untuk mengetahui peran teknologi keuangan dan hambatannya dalam industri kreatif di Indonesia. Adanya inovasi dan kreativitas yang muncul di masyarakat, menjadikan industri kreatif merupakan peran penting dalam pengembangan ekonomi regional. Metode penelitian yang digunakan dalam menulis artikel ini adalah deskriptif kualitatif. Dengan demikian, penelitian kualitatif hanya menggambarkan respons terhadap situasi atau peristiwa sehingga tidak menjelaskan hubungan sebab akibat atau melakukan pengujian hipotesis.
Kata Kunci-Teknologi Keuangan, Industri Kreatif, Internet, Indonesia.

\section{INTRODUCTION}

The internet is one of the technologies widely used by humans in modern times like today. Ranging from children, teens to adults use it for various purposes such as browsing, chatting, and much more. From this internet emerged various applications and websites that help people in their work [13]. Based on the results of the APJI and Polling Indonesia survey in 2018, the number of Internet users is 171.18 million. It will be a lucrative market opportunity for applications, systems and technology to reap the domestic market.

Technology is increasingly developing over time. To make it easier for people to make transactions, check balances and so on, a technology called fintech (Financial Technology). Fintech is a financial service that utilizes technology and software as a forum for the distribution and delivery of information [1]. The background to the emergence of Fintech is when there is a problem in society that cannot be served by the financial industry with various obstacles. Among them are regulations that are too strict as in the bank and the limitations of the banking industry in serving the community in certain areas [2].

Financial technology in Bank Indonesia Regulation Number 19/12 / PBI / 2017 is the use of financial system technology that produces new products, services, technology or business models and can have an impact on monetary stability, financial system stability, efficiency, smoothness, security and payment system reliability. Financial technology providers which include payment systems, market support, investment management and risk management, loans, financing and capital providers, and other financial services. Financial technology or fintech in Indonesia is a very potential market opportunity [3]. The fintech companies are mostly micro, small or medium-sized companies that do not have much equity but have a clear idea of how to introduce new services or how to improve existing services in financial service markets [4].

Fintech develops in various sectors, ranging from payment startups, lending, financial planning (personal finance), retail investment, financing (crowdfunding), remittances, financial research, and others [2]. Like banks, the fintech company's business model also focuses on payment and 
loan services [5]. From the data recorded by the FSA until January 2018 there are 260 thousand people borrowing in the Fintech company in Indonesia. The presence of financial technology is beneficial for people in accessing financial products and makes it easier to conduct financial transactions with a touch of technology in hand. Wherever and whenever people can make transactions without having to come directly to financial companies or waiting in line with various procedures such as banking in general. This can increase financial literacy in Indonesia [6]. Fintech refers to the integration of finance and technology and is different from electronic finance, where electronic finance continues to technically support the existing financial system [7].

Several studies have been conducted previously that discuss the analysis and role of financial technology. One of them is a research conducted by Muzdalifa, Rahma, \& Novalia (2018), which discusses the role of fintech in increasing financial inclusion at MSMEs in Indonesia. The results of the study concluded that the presence of a number of fintech companies also contributed to the development of MSMEs. Not only limited to helping finance venture capital, Fintech's role has also expanded to various aspects such as digital payment services and financial arrangements [1]. Other research has been conducted by Chrismastianto (2017) SWOT analysis discussion related to the installation of financial technology on the quality of banking services in Indonesia. research has analyzed the strengths, weaknesses, opportunities and threats (SWOT) of financial technology installation so that financial technology produces an accurate level of effectiveness in improving the quality of banking services in Indonesia so that banking management can apply it to reach all elements of Indonesian society [8].

In this study, the author will raise the theme of the role of financial technology in the field of creative industries in Indonesia as the subject of the discussion. Creative industries are creativity, expertise and talents that have the potential to improve welfare through offering intellectual creation [9]. The government through the trade department has identified the scope of the creative industry covering 14 sectors including advertising, architecture, the art market, crafts, design, fashion, video, interactive games, music, performing arts, publishing and printing, software, television and radio, research and development [10]. The entry of fintech is a new breakthrough in aspects of business in Indonesia to become more efficient and comfortable [11], this is what can support the development of fintech in the field of creative industries. Creative industries make a significant economic contribution. Also, the creative industry creates a favorable business climate and builds the nation's image and identity. On the other hand, the creative industry is based on renewable resources, creates innovation and creativity, which is a competitive advantage of a nation and has a positive social impact [9]. Because of the increasingly visible role of financial technology in various fields in modern times like now, the authors will conduct research aimed at analyzing the role of fintech and its constraints in the creative industries in Indonesia.

\section{METHOD}

The research method used in writing this article is descriptive qualitative [14]. Qualitative research methods are research methods based on postpositivism philosophy, or interpretative and constructive paradigms, which view social reality as something holistic or intact, complex, dynamic, full of meaning and symptom relations are interactive and are used to examine natural conditions of objects, not an experiment, where the researcher as a critical instrument, data collection techniques carried out by triangulation (combined), data analysis is inductive or qualitative and the results of the study emphasize the meaning rather than generalization. This study uses a qualitative method to determine the role and constraints of fintech in the creative industries [15].

Qualitative descriptive research is aimed at gathering actual and detailed information, identifying problems, making comparisons or evaluations, and determining what other people are doing in dealing with similar problems and learning from their experiences to establish plans and decisions in the future [4]. Thus, qualitative research only describes responses to situations or events, so it does not explain causality or do hypothesis testing.

\section{RESULTS AND DISCUSSION}

In the current era of globalization, the role of financial technology is developing so rapidly for the world economy, one of which is in the field of creative industries. The purpose of this study is to find out the role of fintech and its constraints in the creative industry in Indonesia. There are several sub-sectors of the industry or creative economy that have contributed to the country's GDP, as shown in figure 1 below.

\section{BAGAIMANA KONTRIBUSI}

PDB EKONOMI KREATIF MENURUT SUBSEKTOR

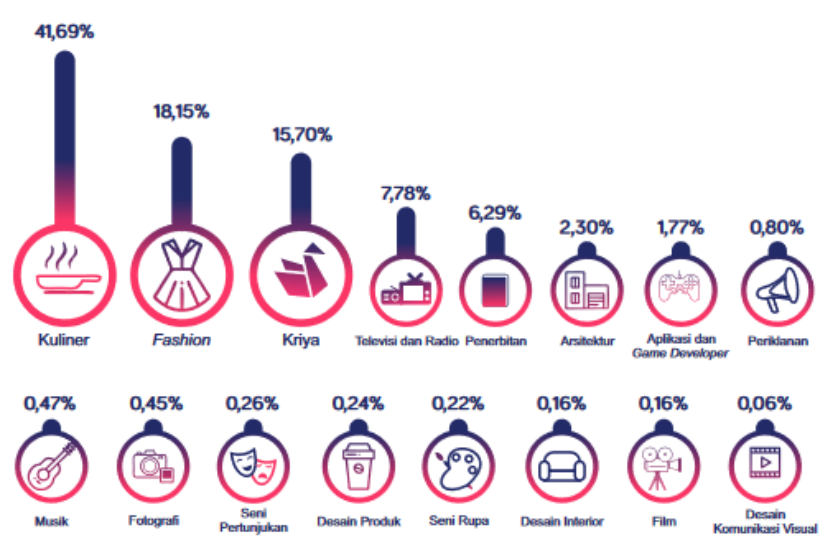

Figure 1. Contribution of Gross Domestic Product in Creative Economy According to Subsector (2016)[12]

From the picture above it can be seen that the creative economy or industry is a sector that has the potential to be processed more deeply to advance the country's economy. With the entry of fintech is expected to be a breath of fresh air for changes in the creative industry sector. The role of fintech in the creative industry is as follows.

\section{Capital Loan}

From the data obtained from BEKRAF (Creative Economy Agency) in 2016 the company's capital results or creative industry businesses are divided into three parts with the following percentage, $92.37 \%$ of companies use their capital, 
$24.44 \%$ of companies make bank loans, and $0.66 \%$ of companies use venture capital. For more details, see in the following figure 2 below.

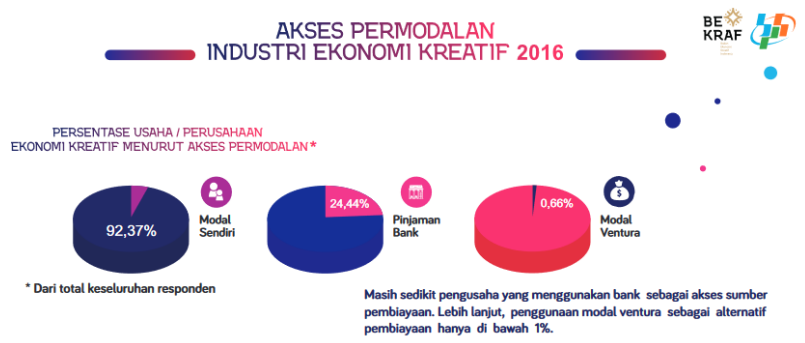

Figure 2. Access to Capital for the Creative Economy Industry 2016[12]

From this data Fintech can be a solution by providing online capital loans with a simpler and more simple submission process by completing the requirements. Several online loan services such as Danamas, Modalku, and Koinworks.

\section{Digital payment services}

The fintech company can also provide digital payments that are easier to fund for entrepreneurs or companies, so that entrepreneurs or companies can make payments safely. Fintech in this field is OVO, Gopay, and Jenius.

\section{Financial Management Services}

Financial management services are services that provide solutions in the areas of recording expenses, monitoring investment performance and financial consulting at no charge. Fintech in this field is a healthy wallet and ngaturduit.com

There are several constraints of companies or businesses in the creative economy. According to data obtained from BEKRAF (Creative Economy Agency), there are several obstacles such as domestic marketing, research and development, physical infrastructure, and others, as shown in the following figure 3 below.

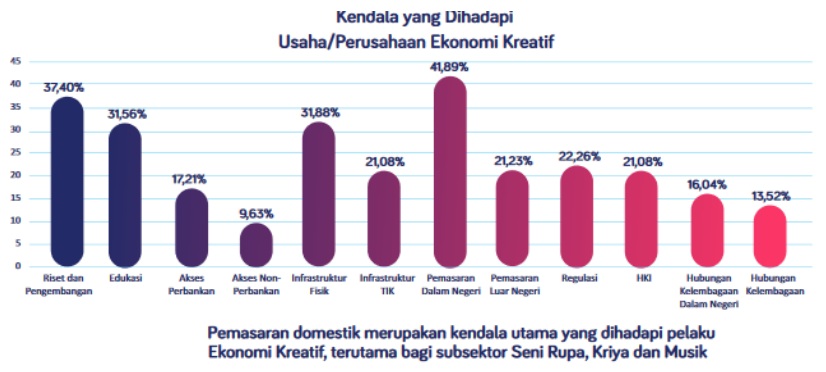

Figure 3. Constraints faced by Creative Economy Enterprises or Companies [12]

In the field of creative industries in Indonesia, the existence of financial technology also has several obstacles, including the following.

\section{IT infrastructure}

IT infrastructure in Indonesia can be said to be uneven, and internet networks can only be felt in big cities like Jakarta, Bandung, Surabaya, and others, while in small cities or remote areas it is still not sure and this is one of Fintech's problems in the creative industry.

\section{Human Resources (HR)}

Lack of human resources (HR) in the regions is one of the obstacles to the spread of fintech making it difficult for fintech to develop. Human resources (HR) should be educated in the regions to spread fintech evenly.

\section{Lack of Financial Literacy}

Many people in rural areas are not familiar with the term fintech about how to use it, its benefits, etc. Not knowing this financial literacy makes financial planning and management in the community not suitable.

\section{CONCLUSION}

Financial technology (fintech) is an innovation in financial services using technology so that people can easily access financial products and services. Fintech can be used to facilitate human being to work, especially in finance such as transactions, checking deposit interest, transferring funds and many other jobs. The presence of several fintech companies contributed to the development of the creative industry in Indonesia. In the current era of globalization, the role of fintech is very diverse and expected to help the creative industry players or companies in developing their businesses.

There are several roles of fintech that can help businesses or companies in developing their businesses, such as capital loans, digital payment services and financial management services. In helping business people or creative industry companies, fintech also experiences several obstacles such as uneven IT infrastructure in Indonesia, lack of human resources, and the lack of public financial literacy regarding fintech.

\section{REFERENCES}

[1] I. Muzdalifa, I. A. Rahma, and B. G. Novalia, "Peran Fintech Dalam Meningkatkan Keuangan Inklusif Pada UMKM Di Indonesia (Pendekatan Keuangan Syariah)," J. Masharif al-Syariah J. Ekon. dan Perbank. Syariah, vol. 3, no. 1, 2018, doi: 10.30651/jms.v3i1.1618.

[2] M. Ansori, "Perkembangan dan Dampak Financial Technology (Fintech) terhadap Industri Keuangan Syariah di Jawa Tengah," Wahana Islam. J. Stud. Keislam., vol. 5, no. 1, pp. 31-45, 2019.

[3] A. Rusydiana, "Bagaimana Mengembangkan Industri Fintech Syariah di Indonesia? Pendekatan Interpretive Structural Model (ISM)," Al-Muzara'ah, vol. 6, no. 2, pp. 117-128, 2018, doi: 10.29244/jam.6.2.117-128.

[4] R. Muchlis, "Schriftenreihe," At-Tawassuth, vol. 3, no. 2, pp. 335-357, 2018, doi: 10.30965/9783846751565_020.

[5] R. R. Suryono, "Financial Technology (Fintech) Dalam Perspektif Aksiologi," Masy. Telemat. Dan Inf. J. Penelit. Teknol. Inf. dan Komun., vol. 10, no. 1, pp. 51-66, 2019, doi: 10.17933/mti.v10i1.138.

[6] T. I. F. Rahma, "Persepsi Masyarakat Kota Medan Terhadap Penggunaan Financial Technology (Fintech)," At-Tawassuth, vol. 3, no. 1, pp. 642-661, 2018.

[7] D. Kurniawan, E. Zusrony, and R. A. Kusumajaya, "Analisa Persepsi Pengguna Layanan Payment 
Gateway Pada Financial Technology Dengan Metode Eucs," J. Inf. Politek. Indonusa Surakarta, vol. 4, no. 3, pp. 1-5, 2018.

[8] I. Adhitya Wulanata Chrismastianto, "Analisis swot implementasi teknologi finansial terhadap kualitas layanan perbankan di indonesia," J. Ekon. dan Bisnis, vol. 20, no. 1, pp. 133-144, 2017.

[9] A. N. Fitriana, I. Noor, and A. Hayat, "Pengembangan Industri Kreatif di Kota Batu (Studi tentang Industri Kreatif Sektor Kerajinan di Kota Batu),"J. Adm. Publik, vol. 2, no. 2, pp. 281-286, 2015.

[10] L. Rahmasari, "Pengaruh Supply Chain Management Terhadap Kinerja perusahaan dan Keunggulan Bersaing (Studi Kasus pada Industri Kreatif di Provinsi Jawa Tengah)," Maj. Ilm. Inform., vol. 2, no. 3, pp. 89-103, 2011.

[11] M. G. Sitompul, "Urgensi Legalitas Financial Technology (Fintech): Peer To Peer (P2P) Lending Di Indonesia," J. Yuridis Unaja, vol. 1, no. 2, pp. 68-79, 2018, doi: 10.35141/jyu.v1i2.428.

[12] Badan Ekonomi Kreatif Indonesia - BEKRAF. "Data Statistik Dan Hasil Survei Khusus Ekonomi Kreatif." Data Statistik Dan Hasil Survei Khusus Ekonomi Kreatif, Kerjasama Badan Ekonomi Kreatif Dan Badan Pusat Statistik, 8 Mar. 2017, www.bekraf.go.id/pustaka/page/data-statistik-danhasil-survei-khusus-ekonomi-kreatif.

[13] A. L. Hananto and B. Priyatna, "Rancang Bangun Aplikasi Informasi Harga Produk Pangan Dan Sembako Di Pasar Kab. Karawang," Techno Xplore J. Ilmu Komput. dan Teknol. Inf., vol. 2, no. 1, 2017.

[14] A. M. Siregar, S. Faisal, Y. Cahyana, and B. Priyatna, "Perbandingan Algoritme Klasifikasi Untuk Prediksi Cuaca," J. Account. Inf. Syst., vol. 3, no. 1, pp. 15-24, 2020.

[15] M. Hennink, I. Hutter, and A. Bailey, Qualitative research methods. SAGE Publications Limited, 2020. 